\title{
Penggunaan Virtual Reality Exposure terhadap Simtom Fobia Sosial pada Mahasiswa Saat Melakukan Public Speaking
}

\section{The Use of Virtual Reality Exposure for Social Phobia Symptoms in College Students during Public Speaking}

\author{
Ar. Fatahillah ${ }^{1}$, Thomas Dicky Hastjarjo ${ }^{2}$ \\ ${ }^{1,2}$ Fakultas Psikologi, Universitas Gadjah Mada
}

\begin{abstract}
Social phobia or social anxiety is an excessive fear of social situations, which in a certain situation might cause problems in daily life. This study aimed to determine the changes in students' social phobia level and physiological responses during exposure to a virtual social environment. The hypothesis of this study was that there is a significant effect of virtual reality exposure to the change of physiological responses and levels of social phobia in the students' group who were treated. The research method used was a pretest-posttest control group design with a mixed design as a research design. There were 41 people who met the research criteria. Participants were divided into the experimental group $(n=21)$ and the control group $(n=20)$. The study used the Social Anxiety Disorder Dimensional (SAD-D), Self-Statements During Public Speaking (SSPS), and Biofeedback Procomp5 Infiniti as measuring instruments. Data analysis used the mixed ANOVA technique. The results of this study indicate that there is an insignificant social phobia symptom increase in the experimental group and a significant decrease in the control group $(p<0.05)$. The implications of this study are expected to provide information for further research in providing treatment to people who experience social anxiety with the virtual environment exposure method.
\end{abstract}

Keywords: physiological responses; social phobia; virtual reality exposure

Abstrak. Fobia sosial atau kecemasan sosial merupakan rasa takut yang berlebihan pada situasi sosial. Rasa takut ini terkadang menimbulkan permasalahan dalam kehidupan sehari-hari. Penelitian ini bertujuan untuk mengetahui perubahan tingkat fobia sosial dan respons fisiologis yang terjadi pada mahasiswa saat diberikan paparan/eksposur berupa social exposure lingkungan virtual. Hipotesis pada penelitian ini adalah terdapat pengaruh signifikan virtual reality exposure terhadap perubahan respons fisiologis dan tingkat fobia sosial pada mahasiswa pada kelompok yang diberi perlakuan. Metode penelitian menggunakan desain eksperimen pretest-posttest control design dengan rancangan penelitian berupa mixed design. Terdapat 41 partisipan yang memenuhi kriteria penelitian. Partisipan dibagi ke dalam kelompok eksperimen $(n=21)$ dan kelompok kontrol $(n=20)$. Instrumen penelitian yang digunakan terdiri dari skala Social Anxiety Disorder Dimensional (SAD-D) dan SelfStatements During Public Speaking (SSPS) serta Biofeedback Procomp5 Infiniti. Analisis data menggunakan teknik mixed ANOVA. Hasil penelitian ini menunjukkan bahwa terjadi peningkatan simtom fobia sosial pada kelompok eksperimen secara tidak signifikan dan terjadi penurunan secara signifikan pada kelompok kontrol $(p<0,05)$. Implikasi dari penelitian ini diharapkan dapat memberikan informasi kepada penelitian selanjutnya dalam memberikan perlakuan pada partisipan yang mengalami kecemasan sosial dengan metode eksposur lingkungan virtual.

Kata kunci: fobia sosial; respons fisiologis; virtual reality exposure 
Fobia dibedakan berdasarkan jenis ketakutan yang dialami. Salah satu jenis fobia yang sering terjadi ialah ketakutan dalam berinteraksi atau bersosialisasi dengan orang lain. Sebuah studi yang dilakukan oleh Vriends et al. (2013) meneliti pada 311 mahasiswa Indonesia dan 349 mahasiswa Swiss. Partisipan pada penelitian tersebut mengisi beberapa skala seperti skala Liebowtz Social Anxiety Scale, The Taijin Kyofusho Scale, The SelfConstrual Scale, Self-Report Social Phobia DSM-IV serta penilaian terhadap keinginan dalam mencari bantuan untuk mengatasi ketakutan sosial. Hasil dari penelitian tersebut ditemukan bahwa simtom kecemasan sosial pada sampel Indonesia lebih tinggi dari pada Swiss. Penelitian tersebut juga menemukan tingginya penilaian diri dari hasil self-report fobia sosial pada sampel orang Indonesia sebanyak 15,8\%. Data tersebut menjadi dasar dari penelitian ini.

Fobia sosial atau disebut juga kecemasan sosial merupakan rasa takut yang berlebihan pada aspek lingkungan sosial. Orang dengan fobia sosial percaya bahwa orang lain secara inheren mengkritik mereka (Looyeh et al., 2014). Orang dengan fobia sosial berusaha untuk memperlihatkan kesan positif pada diri mereka (Beek, 1995). Kecemasan sosial menurut Schlenker dan Leary (1982) didefinisikan sebagai kecemasan yang dihasilkan dari prospek atau hadirnya evaluasi yang sifatnya subjektif dalam situasi sosial yang nyata atau membayangkan situasi sosial tersebut. Situasi sosial diartikan sebagai situasi disaat seseorang dapat menjadi fokus perhatian orang lain.

Alternatif perlakuan dalam mengatasi simtom fobia sosial atau kecemasan sosial. Di antaranya seperti pendekatan farmakoterapi, psikoterapi, interpersonal terapi, dan pendekatan psikodinamik (Jorstad-Stein \& Heimberg, 2009). Pendekatan farmakologis telah terbukti secara substansial mengurangi efek penghindaran (avoidance) dan kesulitan psikologis (Blanco et al., 2010). Penggunaan obat tersebut dapat mengurangi kecemasan dan gejala fisik gangguan fobia sosial serta membantu meningkatkan kinerja dalam situasi sosial atau profesional kerja. Pemberian obat dapat juga digabungkan dengan teknik eksposur terhadap situasi yang ditakuti.

Pendekatan Cognitive Behavioral Therapy (CBT) merupakan pendekatan yang berbasis pembelajaran ditujukan untuk membantu pasien menghilangkan inti dari ketakutannya, perilaku menghindar, serta membantu mengelola kecemasannya. Ada berbagai teknik yang diterapkan dalam CBT. Diantaranya yang paling banyak digunakan untuk perlakuan kecemasan sosial seperti restrukturisasi kognitif, eksposur terapi, pelatihan relaksasi, dan pelatihan keterampilan sosial (Holaway \& Heimberg, 2004). Pendekatan CBT dinilai efektif untuk perlakuan fobia sosial (Fava et al., 2001). Salah satu teknik CBT yang populer saat ini adalah teknik eksposur terapi menggunakan virtual reality (VR). Pendekatan CBT dengan menggunakan VR eksposur dapat mengurangi ketakutan dalam melakukan public speaking. Pada skor penilaian diri, partisipan menunjukkan peningkatan yang signifikan dan merasa puas pada perlakuannya (Anderson et al., 2005). 
Pendekatan terapi interpersonal (IPT) didasarkan pada asumsi bahwa gangguan kejiwaan terjadi dan dipertahankan dalam konteks interpersonal. Perlakuan dari terapi interpersonal ini merupakan area masalah interpersonal inti daripada interaksi sosial dan situasi kinerja yang diidentifikasi kemudian diperiksa melalui beberapa teknik misalnya, eksplorasi perasaan dan pikiran yang berkaitan dengan area masalah tersebut, ekspresi emosi, klarifikasi terhadap perasaannya, komunikasi, membuat keputusan, serta roleplay situasi yang ditakuti tetapi tanpa adanya eksposur.

Pendekatan Psikodinamik menganggap bahwa orang-orang dengan fobia sosial mengalami rasa malu dikarenakan kebutuhan dari ketidaksadaran untuk menjadi pusat perhatian, rasa bersalah dan rasa ragu yang berhubungan dengan ketidaksadaran dalam menghilangkan kompetisi sosial, kecemasan berpisah serta kehilangan cinta dari pengasuh. Representasi atau penilaian orang lain diinternalisasi sebagai kritikan, mempermalukan atau ditinggalkan kemudian diproyeksikan ke orang lain untuk menghindari situasi sosial.

Terdapat beberapa faktor yang menyebabkan fobia sosial di antaranya seperti faktor genetik, lingkungan, dan behavioral inhibition (Heimberg \& Becker, 2002). Beberapa penelitian menguji hubungan antara faktor genetik dengan fobia sosial. Salah satunya penelitian dari Kendler et al. (1992) yang mengatakan bahwa transmisi keluarga fobia sosial pada bayi kembar perempuan ditentukan oleh kombinasi antara genetik dan faktor lingkungan tempat individu tersebut hidup, masing-masing sekitar $1 / 3$ dan $2 / 3$. Tingkat kesesuaian fobia sosial lebih tinggi ditemukan pada kembar monozigot (24\%) daripada kembar dizigot (15\%). Hal ini menunjukkan bahwa ada tingkat transmisi genetik fobia sosial (Heimberg \& Becker, 2002).

Sementara itu DSM-V menjelaskan beberapa kriteria individu yang mengalami kecemasan sosial atau fobia sosial. Individu dengan fobia sosial ditandai dengan perasaan takut atau cemas pada satu atau lebih situasi sosial yang memungkinkan individu tersebut dinilai atau diawasi oleh orang lain. Contohnya termasuk interaksi sosial seperti melakukan percakapan, bertemu dengan orang yang tidak dikenal, makan dan minum di tempat umum, serta tampil di depan orang lain atau memberikan pidato/public speaking.

Kriteria lainnya seperti takut pada situasi yang memungkinkan individu tersebut dievaluasi negatif. Misalnya dapat membuatnya merasa malu atau menyebabkan penolakan atau menyinggung perasaan orang lain. Takut pada situasi yang selalu memicu ketakutan atau kecemasannya. Ketakutan yang sangat intens pada situasi sosial. Kecemasan, ketakutan atau sikap menghindari objek sosial persisten terjadi selama enam bulan atau lebih. Hal tersebut akan mengganggu dan bermasalah pada pekerjaannya atau bagian penting lainnya. Rasa takut, cemas dan penghindaran pada situasi sosial tersebut bukan disebabkan oleh efek fisiologis dari suatu zat atau obat-obatan

Penggunaan virtual reality dalam penelitian ini ditujukan sebagai mediasi eksposur situasi sosial pada saat melakukan presentasi di depan kelas. Tujuan dari penelitian ini adalah untuk menguji pengaruh virtual reality exposure dalam menurunkan simtom fobia 
sosial pada mahasiswa saat melakukan public speaking. Penelitian ini berfokus pada teknik eksposur untuk treatment fobia sosial. Terapi eksposur dengan virtual reality atau disebut juga dengan istilah VRET (Virtual Reality Exposure Therapy). VRET menjadi salah satu sarana dalam melakukan treatment pada orang yang mengalami gangguan kecemasan sosial. Sementara itu eksposur merupakan salah satu teknik terapi untuk pengobatan orang yang mengalami fobia atau gangguan kecemasan. Menurut Neudeck dan Wittchen (2012) eksposur adalah komponen dari treatment pada pasien dengan cara pasien tersebut diberikan penjelasan tentang gangguannya, disiapkan dan dilengkapi dengan pemikiran rasional terhadap perubahan terapeutik dan rangsangan eksternal dan internal yang dihindari atau ditakuti.

Virtual reality exposure merupakan alternatif metode eksposur terapi yang memaparkan objek atau situasi yang ditakuti dalam lingkungan virtual sebagai stimulusnya disaat penggunaan in vivo exposure therapy dirasa terlalu sulit untuk dikendalikan, dan tidak nyaman bagi pasien awal (Anderson et al., 2003). Adapun hipotesis dari penelitian ini adalah virtual reality exposure dapat menurunkan simtom fobia sosial pada kelompok yang diberi perlakuan. Penurunan simtom fobia sosial dilihat berdasarkan skala Self-Statement during Public Speaking (SSPS).

\section{Metode}

\section{Desain penelitian}

Penelitian ini menggunakan desain eksperimen pretest-posttest control design. Partisipan dibagi menjadi dua kelompok yakni kelompok eksperimen dan kelompok kontrol. Kelompok eksperimen yang diberi perlakuan berupa praktik public speaking setelah diberikan sesi eksposur. Sementara itu kelompok kontrol tidak diberi perlakuan. Pengelompokkan dilakukan secara acak dengan cara diundi menggunakan randomizer.org. Rancangan eksperimen yang digunakan dalam penelitian terlihat pada Tabel 1.

\section{Tabel 1.}

Rancangan Eksperimen

\begin{tabular}{lcccc}
\hline Group & & Pretest & Treatment & Posttest \\
\hline Eksperimen & $\mathrm{R}$ & $\mathrm{O}_{1}$ & $\mathrm{X}$ & $\mathrm{O}_{2}$ \\
\hline Kontrol & $\mathrm{R}$ & $\mathrm{O}_{1}$ & & $\mathrm{O}_{2}$ \\
\hline
\end{tabular}

\section{Subjek penelitian}

Subjek berasal dari mahasiswa berkisar berumur 18-25 tahun. Subjek direkrut dari informasi yang disebar di berbagai media sosial seperti Facebook, LINE, Instagram, dan WhatsApp. Jumlah subjek dari penelitian ini berkisar 40-50 mahasiswa. Kategori 
partisipan dipilih dari skor skala Social Anxiety Disorder-Dimensional (SAD-D) dengan kriteria sedang dan tinggi.

\section{Instrumen penelitian}

Variabel dalam penelitian ini adalah virtual reality exposure dan fobia sosial. Definisi fobia sosial merupakan gangguan kecemasan yang berlebihan yang sifatnya persisten khususnya dalam melakukan interaksi sosial dengan orang lain. Skala yang digunakan untuk mengukur tingkat fobia sosial menggunakan skala SSPS (Self-Statement during Public Speaking) yang dikembangkan oleh Hofmann dan Dibartolo (2000). Semakin tinggi skor yang didapatkan partisipan maka mengindikasikan semakin tinggi simtom fobia sosial. Virtual Reality Exposure merupakan teknologi interaktif yang dapat memunculkan kesan immersive pada pengguna yang dapat memvirtualkan objek nyata dalam bentuk tiga dimensi. Pemaparan objek sosial pada saat melakukan public speaking menggunakan VIVE HTC yang dikoneksikan dengan PC Windows 10. VIVE HTC ini dikembangkan oleh HTC (High Tech Computer) Corporation.

Instrumen penelitian yang digunakan terdiri dari beberapa skala untuk mengukur fobia sosial yaitu Social Anxiety Disorder Dimensional (SAD-D) dan skala Self-Statements During Public Speaking (SSPS). Berikut pemaparan masing-masing skala tersebut.

\section{Social Anxiety Disorder Dimensional (SAD-D)}

Social Anxiety Disorder Dimensional (SAD-D) adalah skala yang digunakan untuk melakukan asesmen fobia sosia yang terdiri dari 10 butir. Hasil uji validitas isi pada skala SAD-D dari rentang angka 0,75 hingga 0,95. Berdasarkan Aiken's $V$ dengan jumlah rater enam orang dengan lima pilihan jawaban nilai yang harus dipenuhi sebesar 0,79. Terdapat satu butir yang gugur dikarenakan skor Aiken's $V$ yang diperoleh di bawah dari 0,79 . Sementara itu, besar koefisien reliabilitas yang didapat pada skala SAD-D sebesar $\alpha$ $=0,893$.

\section{Self-Statements During Public Speaking (SSPS)}

Skala Self-Statements During Public Speaking (SSPS) digunakan untuk mengetahui tingkat kecemasan seseorang saat melakukan public speaking yang terdiri dari 10 butir. Skala SSPS nilai Aiken's $V$ yang didapat dari rentang 0,5 hingga 0,95. Terdapat satu butir yang gugur dikarenakan skor Aiken's $V$ yang diperoleh di bawah dari 0,79. Besar koefisien reliabilitas sebelum menggugurkan satu butir yang memiliki nilai korelasi butir total di bawah 0,79 ialah $\alpha=0,635$. Setelah menggugurkan satu butir tersebut nilai reliabilitas skala SSPS meningkat menjadi 0,68 .

\section{Biofeedback Procomp5 Infiniti}

Untuk mengukur perubahan respons fisiologis yang terjadi pada partisipan dengan menggunakan Biofeedback Procomp5 Infiniti yang dikembangkan oleh Thought Technology 
$L t d$. Kemudian untuk menampilkan objek lingkungan virtualnya menggunakan VR VIVE HTC. Subjek secara bertahap akan diperlihatkan stimulus lingkungan sosial berupa lingkungan virtual saat melakukan presentasi di hadapan audiens (virtual audience).

\section{Prosedur penelitian}

\section{Uji coba validitas isi alat ukur}

Sebelum dilakukan eksperimen seluruh skala yang digunakan harus melewati prosedur uji coba validitas isi. Untuk memastikan bahwa alat ukur dapat mengukur objek ukur sesuai dengan penelitian, maka dilakukan prosedur uji coba validitas isi yang dilakukan oleh para expert. Skala Self-Statements During Public Speaking (SSPS) akan dinilai validitas isinya dengan menggunakan teknik Aiken's $V$. Teknik Aiken's $V$ ditujukan untuk menghitung koefisien validitas isi didasarkan pada hasil penilaian ahli terhadap suatu butir dari segi sejauh mana item tersebut dapat mewakili konstruk yang diukur (Azwar, 2012).

\section{Uji presence}

Selanjutnya dilakukan proses uji coba lingkungan virtual reality atau disebut uji presence. Uji coba presence ditujukan untuk mengevaluasi environment atau lingkungan virtual yang digunakan sesuai dalam penelitian ini. Skala yang digunakan adalah presence questionnaire yang dikembangkan oleh Witmer et al. (2005). Sebelum melakukan proses uji pressence, skala yang akan digunakan terlebih dahulu melewati proses expert judgment. Selanjutnya dilakukan perekrutan partisipan yang akan mengikuti eksperimen. Penelitian ini diikuti sebanyak 101 partisipan yang mengisi skala social anxiety disorder dimensional (SAD-D). Setelah dilakukan penyeleksian berdasarkan skor dari partisipan. Terdapat 41 subjek yang memenuhi kriteria penelitian. Kemudian partisipan dikelompokkan menjadi kelompok eksperimen dan kelompok kontrol. Pada kelompok eksperimen berjumlah 21 orang partisipan dan kelompok kontrol berjumlah 20 orang partisipan. Subjek terdiri dari 16 laki-laki dan 25 perempuan. Selanjutnya partisipan diberikan eksposur secara bertahap dengan tiga kali sesi. Berikut gambar lingkungan virtual yang digunakan sebagai objek eksposur: 


\section{Gambar 1.}

\section{Lingkungan Virtual}
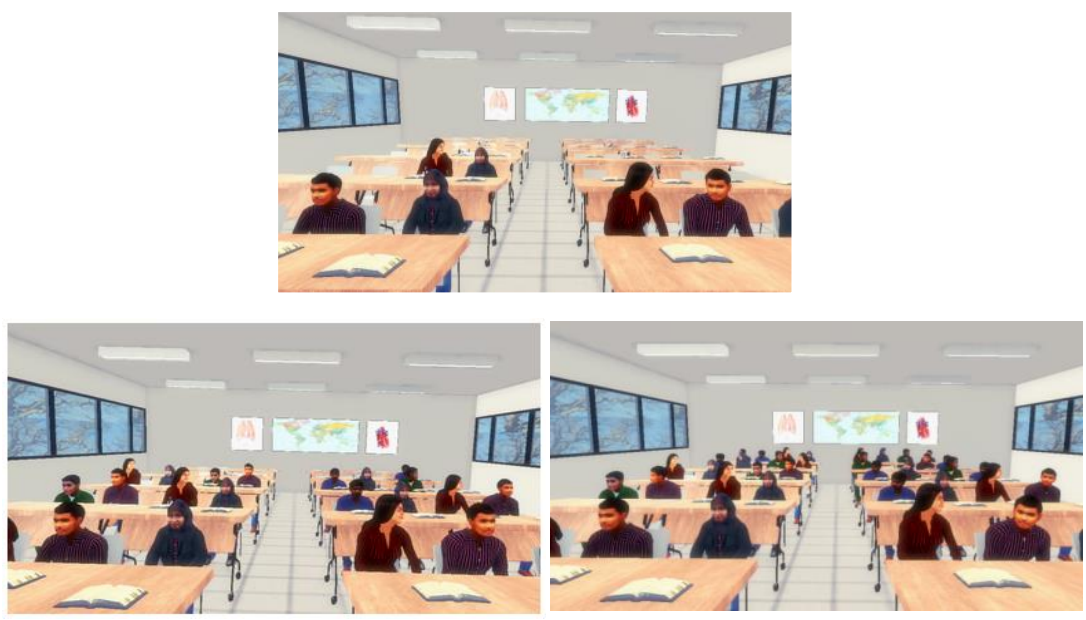

\section{Teknik analisis}

Prosedur analisis diambil dari data pretest dan posttest dengan menggunakan analisis mixed ANOVA melalui pengukuran biofeedback untuk mengukur perubahan respons fisiologis berupa perubahan tingkat kelenjar keringat, pernapasan, detak jantung. Skala SSPS dari Hofmann dan Dibartolo (2000) juga dilakukan prosedur analisis. Analisis menggunakan IBM SPSS Statistics versi 23. Terdapat beberapa asumsi yang harus dipenuhi pada teknik analisis mixed ANOVA. Diantaranya seperti 1) penempatan secara acak pada setiap kelompok; 2) data merupakan data interval; 3) terdistribusi secara normal; 4) varians data homogen (Ramsey, 2007).

\section{Hasil}

Tabel 2 menunjukkan rata-rata skor dan standar deviasi pada kelompok kontrol dan kelompok eksperimen tidak jauh berbeda pada saat pretest dan posttest. Rata-rata skor dan standar deviasi pada kelompok eksperimen sebesar 26,19 dan 3,21. Sementara itu pada kelompok kontrol skor rata-rata dan standar deviasi diperoleh sebesar 27,06 dan 3,91.

Tabel 2.

Deskripsi Data Statistik Penelitian

\begin{tabular}{lcccccccc}
\hline \multirow{2}{*}{ Skor } & \multicolumn{4}{c}{ Eksperimen } & \multicolumn{5}{c}{ Kontrol } \\
\cline { 2 - 10 } & Mean & SD & Maks & Min & Mean & SD & Maks & Min \\
\hline Pretest & 26,19 & 3,21 & 31 & 21 & 27,06 & 3,91 & 34 & 20 \\
Posttest & 16,67 & 3,69 & 32 & 21 & 25,5 & 3,88 & 34 & 19 \\
\hline
\end{tabular}


Pada posttest terlihat bahwa terdapat perbedaan pada rata-rata skor kelompok kontrol dengan kelompok eksperimen. Kelompok kontrol memperoleh skor rata-rata lebih besar dibandingkan dengan skor rata-rata kelompok eksperimen dengan rata-rata skor sebesar 25,5 dan standar deviasi sebesar 3,88. Pada kelompok eksperimen skor ratarata dan standar deviasi yang diperoleh sebesar 16,67 dan 3,69.

Uji normalitas ditujukan untuk melihat apakah data berdistribusi normal atau tidak. Data dikatakan berdistribusi normal apabila nilai signifikansi yang diperoleh lebih dari 0,05 ( $p>0,05)$, sebaliknya jika nilai signifikansi yang didapat kurang dari 0,05 maka data dikatakan tidak terdistribusi secara normal.

\section{Tabel 3.}

Uji Normalitas Data

\begin{tabular}{cccc}
\hline Kelompok & Skor & \multicolumn{2}{c}{ Shapiro-Wilk } \\
\cline { 3 - 4 } & & Statistik & Sig. $(p)$ \\
\hline Eksperimen & Pretest & 0,932 & $0,152^{*}$ \\
& Posttest & 0,980 & $0,947^{*}$ \\
Kontrol & Pretest & 0,896 & 0,029 \\
& Posttest & 0,965 & $0,695^{*}$ \\
\hline
\end{tabular}

Ket: ${ }^{*}=\operatorname{normal}(p>0,05)$

Tabel 3 menunjukkan hasil uji normalitas data. Tabel 3 memperlihatkan bahwa seluruh data terdistribusi normal kecuali pada skor pretest kelompok kontrol. Skor pretest dan posttest yang didapat pada kelompok eksperimen masing-masing sebesar 0,152 dan 0,947 . Sementara itu skor pretest dan posttest pada kelompok kontrol masing-masing sebesar 0,029 dan 0,695. Hal ini menunjukkan bahwa seluruh data terdistribusi secara normal $(p>0,05)$, kecuali pada data prestest kelompok kontrol yang memiliki nilai $p$ kurang dari 0,05 $(p<0,05)$. Ketidaknormalan yang terjadi pada data dapat diabaikan karena pada analisis ANOVA termasuk uji nilai $F$ yang kebal atau robust terhadap ketidaknormalan data (Ramsey, 2007).

Uji homogenitas ditujukan untuk melihat varians data yang digunakan bersifat homogen atau tidak. Data dikatakan homogen jika taraf signifikansi lebih dari 0,05 atau ( $p$ $>0,05)$, data dikatakan heterogen apabila nilai signifikansi kurang dari 0,05 atau $(p<0,05)$. Hasil dari uji homogenitas pada data menunjukkan bahwa data dikatakan homogen. Nilai signifikan yang didapat sebesar 0,175 atau lebih besar dari 0,05 $(p>0,05)$. 
Tabel 4.

Hasil Uji Hipotesis

\begin{tabular}{llrrrrrr}
$\begin{array}{l}\text { Measure } \\
\text { Source }\end{array}$ & Fobia Sosial & $\begin{array}{c}\text { Type III } \\
\text { Sum of } \\
\text { Squares }\end{array}$ & df & $\begin{array}{l}\text { Mean } \\
\text { Square }\end{array}$ & F & Sig. & $\boldsymbol{\eta}^{2}$ \\
\hline $\begin{array}{l}\text { PreTestPos } \\
\text { Test * KLP }\end{array}$ & $\begin{array}{l}\text { Sphericity } \\
\text { Assumed }\end{array}$ & 20,005 & 1 & 20,005 & 9,633 & 0,004 & 0,207 \\
\cline { 2 - 8 } & $\begin{array}{l}\text { Greenhouse- } \\
\text { Geisser }\end{array}$ & 20,005 & 1,000 & 20,005 & 9,633 & 0,004 & 0,207 \\
& & & & & & \\
\hline
\end{tabular}

Tabel 4 menunjukkan bahwa terdapat interaksi antara pretest dan postest dengan kelompok (eksperimen dan kontrol). Interaksi yang terjadi menandakan bahwa perubahan skor pada pretest dan postest serta pada kelompok eksperimen dan kontrol berbeda secara signifikan. Baris PreTestPostTest*KLP dan subbaris Greenhouse-Geisser pada tabel diatas memperoleh nilai $F=9,33$ dan nilai $\operatorname{sig}=0,04$ atau $(p<0,05)$.

Tabel 5 menunjukkan bahwa perubahan kecenderungan fobia sosial pada kedua kelompok yakni kelompok eksperimen dan kontrol. Jika nilai Mean Difference (MD) bernilai positif maka mengandung arti bahwa subjek mengalami penurunan atau rerata skor pretest lebih tinggi dari rerata skor postest, namun jika $M D$ bernilai negatif berarti subjek mengalami peningkatan atau rerata skor postest lebih tinggi dari rerata skor prestest. Pada kelompok eksperimen terjadi peningkatan yang tidak signifikan $(M D=-$ 0,476; $p>0,05)$. Sementara itu pada kelompok kontrol mengalami penurunan yang signifikan $(M=1,556 ; p<0,05)$.

\section{Tabel 5.}

Hasil Pairwise Comparisons

\begin{tabular}{|c|c|c|c|c|c|c|c|}
\hline \multirow[t]{3}{*}{ KLP } & & & \multirow{3}{*}{$\begin{array}{c}\text { Mean } \\
\text { Difference (I- } \\
\mathrm{J})\end{array}$} & \multirow[t]{3}{*}{$\begin{array}{l}\text { Std. } \\
\text { Error }\end{array}$} & \multirow[t]{3}{*}{ Sig. ${ }^{b}$} & \multicolumn{2}{|c|}{$\begin{array}{c}\text { Taraf Kepercayaan } \\
95 \%\end{array}$} \\
\hline & & & & & & Batas & Batas \\
\hline & & & & & & Bawah & Atas \\
\hline \multirow[t]{2}{*}{ Eksperimen } & 1 & 2 & $-0,476$ & 0,445 & 0,291 & $-1,377$ & 0,425 \\
\hline & 2 & 1 & 0,476 & 0,445 & 0,291 & $-0,425$ & 1,377 \\
\hline \multirow[t]{2}{*}{ Kontrol } & 1 & 2 & $1,556^{*}$ & 0,480 & 0,003 & 0,582 & 2,529 \\
\hline & 2 & 1 & $-1,556^{*}$ & 0,480 & 0,003 & $-2,529$ & $-0,582$ \\
\hline
\end{tabular}

Hasil dari multivariate test menunjukkan besaran sumbangsih efek perlakuan yang diberikan. Kelompok eksperimen memperoleh nilai partial eta squared sebesar 0,03 yang artinya pemberian efek perlakuan berupa melakukan public speaking cenderung 
meningkatkan simtom fobia sosial pada subjek sebesar 3\% namun secara tidak signifikan. Sementara itu pada kelompok kontrol terjadi penurunan kecenderungan fobia sosial pada subjek sebesar $22 \%$ secara signifikan. Terjadinya peningkatan tingkat fobia sosial pada kelompok eksperimen ini terjadi dikarenakan eksposur yang diberikan dilakukan dalam satu kali sesi dan diakhiri dengan melakukan public speaking.

\section{Diskusi}

Berdasarkan hasil analisis menggunakan mixed ANOVA pada skala SSPS ditemukan bahwa terjadi peningkatan skor pada kelompok eksperimen. Artinya bahwa pada kelompok eksperimen mengalami kecemasan setelah diberikan treatment yaitu melakukan public speaking. Sementara itu pada kelompok kontrol justru mengalami penurunan skor. Artinya bahwa pada kelompok kontrol mengalami penurunan tingkat kecemasan setelah sesi eksposur diberikan. Huffman (2010) berpendapat bahwa sistem saraf simpatetik yang aktif memiliki fungsi untuk meningkatkan denyut jantung, respirasi dan respons "fight-orflight". Ketika partisipan kelompok eksperimen diberikan treatment, partisipan cenderung mengaktifkan sistem saraf simpatetik. Sementara pada kelompok kontrol cenderung mengaktifkan sistem saraf parasimpatetik hal ini terlihat dari skor yang didapatkan pada posttest yang menurun. Hal ini menandakan bahwa partisipan mencoba untuk menenangkan tubuh dalam kondisi rileks dan mempertahankan kondisi homeostatis atau mengembalikan tubuh ke kondisi awal (Huffman, 2010).

Penelitian lain yang dilakukan oleh Owens dan Beidel (2014) yang melibatkan partisipan dengan kecemasan sosial dengan yang tidak mengalami kecemasan sosial. Penelitian tersebut juga menggunakan skala SSPS untuk menilai subjektif distres pada saat diberikan eksposur lingkungan VR dan in vivo. Hasil dari penelitian tersebut menunjukkan bahwa lingkungan VR signifikan meningkatkan subjektif distress pada kelompok yang mengalami kecemasan sosial.

Penurunan skor pada kelompok eksperimen terjadi dikarenakan terdapat jeda dan tidak diberikan tugas berupa public speaking sebelum dilakukan pengukuran posttest. Hal ini membuat partisipan menjadi rileks setelah diberikan eksposur. Berbeda dengan kelompok eksperimen yang diberikan tugas praktik public speaking. Kecemasan partisipan kelompok eksperimen meningkat disebabkan karena eksposur yang diberikan dalam satu kali sesi. Sementara itu pada penelitian lain yang dilakukan oleh Anderson et al. (2003) yang melibatkan partisipan dengan kriteria mengalami fobia sosial. Partisipan diberikan eksposur secara bertahap hingga delapan kali sesi eksposur. Hasil dari penelitian tersebut menyatakan bahwa VR berguna untuk eksposur terapi pada treatment kecemasan sosial. Setelah pemberian treatment, partisipan pada penelitian tersebut merasa kecemasannya menurun dan mulai mampu melakukan kontrol diri jika dihadapkan situasi public speaking. Sejalan dengan ini, penelitian yang dilakukan oleh Reeves et al. (2021) temuannya menunjukkan bahwa partisipan yang mengikuti sesi VR eksposur terapi 
secara signifikan kecemasan public speaking-nya relatif menurun setelah melewati 4 kali sesi.

Sementara itu hasil dari uji mixed ANOVA pada data respons fisiologis juga menunjukkan perubahan pada heart rate secara signifikan. Tidak ditemukan hasil yang signifikan pada pengukuran respiration rate dan skin conductance. Sejalan dengan temuan tersebut pada penelitian yang dilakukan oleh Owens dan Beidel (2014) menemukan bahwa terjadi peningkatan pengukuran heart rate secara signifikan. Hal ini menunjukkan bahwa partisipan saat diberikan tugas kurang mampu untuk melakukan kontrol diri atas respons fisiologis mereka. Hal ini terjadi dikarenakan partisipan diperlihatkan eksposur virtual berupa lingkungan public speaking. Berbeda dengan hasil penelitian yang ditemukan oleh Owens dan Beidel (2014). Temuan lain dari penelitian ini tidak ditemukan hasil yang signifikan pada pengukuran respiration rate dan skin conductance.

Analisis tambahan menggunakan uji one way ANOVA pada respons fisiologis saat eksposur sesi 1-2 dan eksposur sesi 2-3 menemukan bahwa tidak terjadi perbedaan yang signifikan pada kelompok eksperimen maupun kelompok kontrol. Tujuan dilakukannya analisis tambahan ini adalah untuk melihat perbedaan respons fisiologis yang terjadi pada saat eksposur diberikan. Hasilnya menunjukkan bahwa tidak ditemukan hasil yang signifikan perbedaan respons fisiologis pada kelompok kontrol dengan kelompok eksperimen. Hal ini disebabkan karena eksposur lingkungan virtual yang diperlihatkan sama pada masing-masing kelompok sehingga memunculkan respons yang sama pada kedua kelompok tersebut. Berbeda ketika diberikan treatment berupa tugas melakukan public speaking di akhir sesi eksposur pada kelompok eksperimen sehingga memunculkan perasaan cemas dikarenakan diberikan perintah melakukan public speaking setelah diperlihatkan stimulus sosial.

Hasil dari penelitian ini diharapkan dapat dikembangkan lagi pada penelitian selanjutnya. Hal ini dikarenakan masih terdapat keterbatasan dalam melakukan penelitian ini. Diantaranya seperti lingkungan virtual yang digunakan masih perlu untuk di kembangkan agar lebih interaktif. Penggunaan virtual reality telah terbukti efektif dalam menangani kecemasan dan ketakutan yang dialami oleh partisipan. Terbatasnya facial expression pada lingkungan virtual menjadi salah satu keterbatasan dalam memberikan treatmen (Mutianingsih \& Hariyati, 2018). Hal ini berhubungan dikarenakan partisipan memiliki ketakutan dinilai negatif di depan umum maupun saat melakukan interaksi langsung secara tatap muka. Sehingga dapat meningkatkan rasa hadir di dalam lingkungan virtual tersebut. Menanamkan rasa hadir secara virtual bermanfaat untuk memicu rasa takut yang relevan dengan lingkungan alaminya (Reeves et al., 2021).

Kedua, partisipan dari penelitian ini belum mempertimbangkan pengalaman organisasi dan tingkat pendidikan pada partisipan. Hal ini dikarenakan partisipan yang memiliki pengalaman organisasi akan terbiasa jika dihadapkan dengan situasi sosial. Memilih partisipan yang beragam seperti jenis kelamin, pendidikan, status, usia dan 
pengalaman organisasi harus diutamakan (Reeves et al., 2021). Penelitian lain menunjukkan bahwa eksposur terapi menggunakan VR terbukti efektif pada orang dewasa yang mengalami kecemasan saat berbicara di depan umum (Kahlon et al., 2019).

\section{Kesimpulan}

Berdasarkan hasil analisis skala SSPS tersebut ditemukan bahwa terjadi peningkatan yang tidak signifikan skor posttest pada kelompok eksperimen dan terjadi penurunan secara signifikan pada kelompok kontrol. Sementara itu pada hasil pengukuran respons fisiologis menunjukkan tidak adanya perbedaan yang signifikan antara kelompok kontrol dan kelompok eksperimen pada masing-masing pengukuran. Sehingga hipotesis yang diajukan ditolak.

\section{Saran}

Saran pada penelitian berikutnya adalah perlu mempertimbangkan faktor lain dari subjek seperti tingkat kecenderungan presence, tingkatan kecemasan terhadap lingkungan sosial, serta partisipan dengan kriteria kecemasan sosial yang rendah, direkomendasikan untuk diuji lebih lanjut pengaruh virtual reality melalui metode virtual reality exposure therapy, mengkombinasikan VR dengan Cognitive Behavioral Therapy (CBT) atau Cognitive Restructuring, memperhatikan variabel extraneous yang bisa saja terjadi pada saat pengambilan data. Seperti efek belajar pada saat pengisian skala serta kondisi ruangan serta pengalaman organisasi partisipan, perlu melibatkan ahli dibidang 3D atau animasi untuk membuat lingkungan virtual yang lebih interaktif serta menyesuaikan konteks di Indonesia.

\section{Ucapan terima kasih}

Penulis mengucapkan banyak terima kasih kepada seluruh pihak yang terlibat dalam membantu penelitian ini. Penulis juga mengucapkan terima kasih kepada Almarhum Dr. Neila Ramdhani, M.Si., M.Ed yang telah menginisiasi penelitian ini. Serta teman-teman Tim Penelitian VR yang telah memberikan dukungan penuh dalam menyelesaikan penelitian ini.

\section{Kontribusi penulis}

Arf merancang, menganalisis serta menulis naskah, dan Hj sebagai Dosen Pembimbing Skripsi

\section{Konflik kepentingan}

Penulis menyatakan tidak terdapat konflik kepentingan dalam penelitian, penulisan maupun publikasi artikel ini. 


\section{Kepustakaan}

Anderson, P. L., Zimand, E., Hodges, L. F., \& Rothbaum, B. O. (2005). Cognitive behavioral therapy for public-speaking anxiety using virtual reality for exposure. Depression and Anxiety, 22, 156-158.

Anderson, P., Rothbaum, B. O., \& Hodges, L. F. (2003). Virtual reality exposure in the treatment of social anxiety. Cognitive and Behavioral Practice, 10(3), 240-247. https://doi.org/10.1016/S1077-7229(03)80036-6

Azwar, S. (2012). Reliabilitas dan validitas (Edisi keempat). Pustaka Pelajar.

Beek, J. (1995). Overcoming Social Phobia; Patient Self-Help Guide "Theory Book". Amsterdam.

Blanco, C., Schneier, F. R., Okuda, M., \& Liebowitz, M. R. (2010). Psychopharmacology for social anxiety disorder. Dalam S. G. Hofmann, \& P. M. DiBartolo, Social Anxiety: Clinical, Developmental, and Social Perspectives (Edisi kedua) (hal. 490-512). Academic Press.

Fava, G. A., Grandi, S., Rafanelli, C., Ruini, C., Conti, S., \& Belluardo, P. (2001). Long-term outcome of social phobia treated by exposure. Psychological Medicine, 31(5), 899905. https://doi.org/10.1017/S0033291701004020.

Heimberg, R. G., \& Becker, R. E. (2002). Cognitive-behavioral group therapy for social phobia: Basic mechanisms and clinical strategies. The Guilford Press.

Hofmann, S. G., \& Dibartolo, P. M. (2000). An instrument to assess self-statements during public speaking: Scale development and preliminary psychometric properties. Behavior Therapy, 31(3), 499-515. https://doi.org/10.1016/s0005-7894(00)80027-1.

Huffman, K. (2010). Psychology in action (Edisi kesembilan). John Wiley \& Sons, Inc.

Jorstad-Stein, E. C., \& Heimberg, R. G. (2009). Social phobia: An update on treatment. Psychiatr Clin, 32(3), 641-663. https://doi.org/10.1016/j.psc.2009.05.003.

Kahlon, S., Lindner, P., \& Nordgreen, T. (2019). Virtual reality exposure therapy for adolescents with fear of public speaking: a non-randomized feasibility and pilot study. Child and Adolescent Psychiatry and Mental Health, 13(1), 47. https://doi.org/10.1186/s13034-019-0307-y

Kendler, K. S., Neale, M. C., Kessler, R. C., Heath, A. C., \& Eaves, L. J. (1992). The genetic epidemiology of phobias in women: The interrelationship of agoraphobia, social phobia, situational phobia, and simple phobia. Archives of General Psychiatry, 49(4), 273-281. https://doi.org/10.1001/archpsyc.1992.01820040025003

Looyeh, M. Y., Kamali, K., MA, A. G., \& Tonawanik, P. (2014). Treating social phobia in children through group narrative therapy. The arts in psychoterapy, 41(1), 16-20. https://doi.org/10.1016/j.aip.2013.11.005.

Holaway, R., \& Heimberg, R.G. (2004). Cognitive-behavioral therapy for social anxiety disorder: A treatment review. Dalam B. Bandelow, \& D. J.Stein, Social Anxiety Disorder (p. 207). Marcel Dekker, Inc. 
Mutianingsih, \& Hariyati, R. S. (2018). Penggunaan virtual reality exposure therapy pada klien dengan gangguan kecemasan :Fobia sosial. Jurnal Kesehatan Bhakti Husada, $4(2)$.

Neudeck, P., \& Wittchen, H. U. (2012). Exposure therapy: Rethinking the Model - Refining the Method. Springer.

Owens, M. E., \& Beidel, D. C. (2014). Can virtual reality effectively elicit distress associated with social anxiety disorder? Journal of Psychopathology and Behavioral Assessment, 37(2). https://doi.org/10.1007/s10862-014-9454-xJ

Ramsey, P. H. (2007). Factorial design. Dalam N. J. Salkind, \& K. Rasmussen, Encyclopedia of Measurement and Statistics (Vol.2). SAGE Publications.

Reeves, R., Elliott, A., Curran, D., Dyer, K., \& Hanna, D. (2021). 360 Video virtual reality exposure therapy for public speaking anxiety: A randomized controlled trial. Journal of Anxiety Disorders, 83, 102451. https://doi.org/10.1016/j.janxdis.2021.102451.

Schlenker, B. R., \& Leary, M. R. (1982). Social anxiety and self-presentation: A conceptualization and model. Psychological Bulletin, 92(3), 641-669.

Vriends, N., Pfaltz, M.C., Novianti, P., \& Hadiyono, J. (2013). Taijin kyofusho and social anxiety and their clinical relevance in Indonesia and Switzerland. Frontiers in Psychology, 4, 3. https://doi.org/10.3389/fpsyg.2013.00003

Witmer, B. G., Jerome, C. J., \& Singer, M. J. (2005). The factor structure of the presence $\begin{array}{lllll}\text { questionnaire. } & \text { Pressence, } & 14(3), & 298 & -\end{array}$ https://doi.org/10.1162/105474605323384654 